\title{
Xijitan Landslide in Guide Basin in the Upper Reaches of the Yellow River and its Dammed Lakes
}

Qin Xiaoguang ${ }^{1 *}$, Yin Zhiqiang ${ }^{2}$ and Zhao Wuji ${ }^{3}$

${ }^{1}$ Institute of Geology and Geophysics, Chinese Academy of Sciences, Beijing 100029, China

${ }^{2}$ China Institute of Geo-Environment Monitoring, Beijing 100081, China

${ }^{3}$ China University of Geosciences (Beijing), Beijing 100029, China

\begin{abstract}
In the upper reaches of the Yellow River in the northeastern Tibetan Plateau, the uplift of the Tibetan Plateau and the erosion of the Yellow river reformed the landscape of the region and built steep slopes and terraces. A lot of giant landslides developed along the steep valley of the river. However, the influence of landslides to river terraces has been unclear because landslides development stages cannot be identified easily in field survey. In the study, the Xijitan giant landslide was analyzed by combining the remote sense analysis of geological facies and the field survey. The five development stages of the landslide and the related dammed lake were identified by analyzing the topographic features. It was concluded (1) the main Xijitan landslide was triggered by rain during the warm and wet Holocene Optimum period after 6000 a BP. (2) The outburst of the dammed lake of the landslide reformed the dammed body to build a local terrace that is different from other regional river terraces.
\end{abstract}

Keywords: Landslide and its dammed lake; Landslide development stages; Triggering mechanism; Geomorphic evolution

\section{Introduction}

The development of geo hazards, such as landslides and debris flows are closely related to the geomorphic evolution and is a process of the landform reshaping. In order to reveal the response of the geo hazards to the geomorphic evolution, many studies have been carried out by scientists. Chen et al. [1] studied the geological process of the Huangtupo landslide in the Three Gorges reservoir. Liu et al. [2] analyzed the geomorphic characteristics and landslide evolution in Wanzhou City. Chen et al. [3] discussed the landslide development and river channel evolution process of Three Gorges Reservoir. Yin et al. [4-7] studied on giant landslide characteristics and their response to climate change in the upstream of the Yellow river over the past 100 ka years.

The Guide Basin located at the upper reaches of the Yellow River in the northeastern of the Qinghai-Xizang (Tibetan) Plateau. The region is characterized by complex active tectonic and diverse geomorphic type. Landslides, debris flows and other geo hazards frequently happened in the Guide basin greatly reshape the landform and also seriously influence the safety of residents and road traffic in the area.

\section{Geological Settings}

The Guide Basin is a Cenozoic graben basin and surrounded by the Baji Mountain, Waligong Mountain, Zhamazari Mountain and Lajishan Mountain [8]. The basement of the basin is composed of Proterozoic and Triassic stratum, overlaid by the amaranth glutenite, sandstone and silty mudstone of the Xining group, Neocene. The Xining group is unconformable covered by the glutenite and mudstone stratum of the Guide group, Quaternary sediments of the thickness more than $1000 \mathrm{~m}$ [5].

The Yellow River flows through the Guide basin from west to east. In the region, the main terrains types are high mountains, middle mountains, hilly area, and piedmont and valley plains area. The lowest elevation point, $2170 \mathrm{~m}$, of the basin is the Songba gorge where the Yellow River outflow the basin through, while the elevation of the highest ridge is $5011 \mathrm{~m}$ at the edge of the basin. Thus, the terrain elevation difference is very huge. The largest width of the Yellow River valley in the basin is about $5.5 \mathrm{~km}$, while in the narrowest valley is only $3 \mathrm{~km}$ of the Ashigong area. The rock stratum in the valley plain is mainly diluvial-proluvial pebble bed and Holocene diluvial sediment containing pebble. The floodplains and terraces have been reclaimed as arable land, which is the most frequent human economic activities region [9].

In the Guide Basin, there are seven giant landslides, i.e., Xijitan landslide, Chada landslide, Garang landslide, Ashigong landslide, Geza landslide, Songbaxia left-bank landslide and Songbaxia rightbank landslide. Most of them consist of semi-consolidated Tertiary mudstone and siltstone. Four giant landslides of them, named as Xijitan, Geza, Songbaxia and Ashigong landslides, resulted in the formation of dammed lakes (Figure 1). Although the Xijitan landslide has been studied by former scientists, the evolution of the landslide group and its dammed lake are not clear.

In the study, the Xijitan giant landslide and its dammed lakes in Guide basin is chosen to study its evolution and effects on geomorphic evolution by remotely sensed analysis of geological facies and field investigation (Figure 1).

\section{Xijitan Landslide and its Dammed Lake}

Xijitan landslide located at the north shore of the Yellow River in the Guide Basin. The major body of the landslide is about $8 \mathrm{~km}$ long and $3.9 \mathrm{~km}$ wide (Figure 2). For the major landslide body, the altitudes of its trailing edge and its leading edge are about $2800 \mathrm{~m}$ and $2200 \mathrm{~m}$,

*Corresponding author: Qin Xiaoguang, Institute of Geology and Geophysics, Chinese Academy of Sciences, Beijing 100029, China, E-mail: xiaoguangqin@ mail.iggcas.ac.cn

Received April 13, 2015; Accepted June 27, 2015; Published July 04, 2015

Citation: Xiaoguang Q, Zhiqiang Y, Wuji Z (2015) Xijitan Landslide in Guide Basin in the Upper Reaches of the Yellow River and its Dammed Lakes. J Remote Sensing \& GIS 4: 147. doi:10.4172/2469-4134.1000147

Copyright: (c) 2015 Xiaoguang Q, et al. This is an open-access article distributed under the terms of the Creative Commons Attribution License, which permits unrestricted use, distribution, and reproduction in any medium, provided the original author and source are credited. 
Citation: Xiaoguang Q, Zhiqiang Y, Wuji Z (2015) Xijitan Landslide in Guide Basin in the Upper Reaches of the Yellow River and its Dammed Lakes. J Remote Sensing \& GIS 4: 147. doi:10.4172/2469-4134.1000147

Page 2 of 6

respectively. In its trailing edge, the width of the outcropped sliding surface is $0.3 \sim 0.6 \mathrm{~km}$. However, the moving distance of its leading edge is about $2 \mathrm{~km}$. It shows that the $\sim 600 \mathrm{~m}$ height difference resulted in the occurrence of the massive landslide. The front part of the landslide has been incomplete due to river erosion.

\section{Landslide development stages}

According to Remote sensing analysis and field survey, the development of the Xijitan landslide can be divided into five stages.

Stage 1: The main channel of the Yellow River flowed along the north side of the valley due to the effect of Tibetan plateau uplift. The northward-side erosion of the river resulted in the occurrence of steep slopes and in turn to trigger stepped landslide (No. 1) along the north shore (Figure 3a). The landslide had a large width and a short sliding distance. On the remotely sensed image, it can be noticed that the eastern part of the early landslide had been reformed and damaged by the later landslide (Figure 2).

Stage 2: The main body of Xijitan landslide (No. 2) developed in the stage (Figure $3 \mathrm{~b}$ ). The original front edge of the landslide had been seriously eroded by the Yellow river. At the north shore of the Yellow river, the residual hill at the front of the landslide overlies the second terrace of the river (Figure 4a). At another site with same elevation, the second terrace consists of the lower gravel layer and the upper silk sand layer (Figure $4 \mathrm{~b}$ ). At the top of the second terrace, it is sampled for
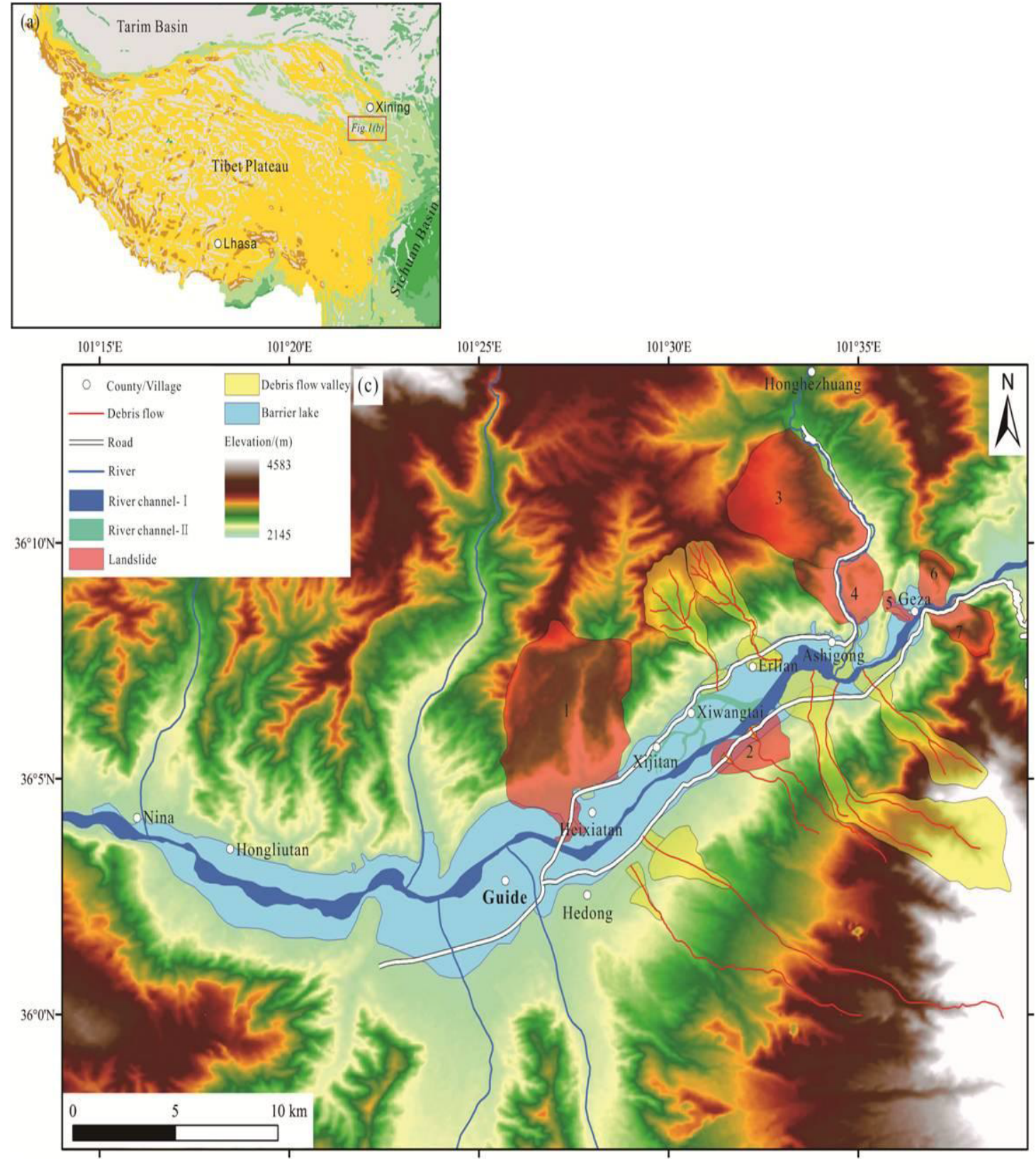

Figure 1: Locations and distribution of landslides, debris flows in the study area, 1. Xijitan landslide, 2. Chada landslide, 3.Garang landslide, 4. Ashigong landslide, 5. Geza landslide, 6. Songbaxia left bank landslide, 7. Songbaxia right bank landslide. 
Citation: Xiaoguang Q, Zhiqiang Y, Wuji Z (2015) Xijitan Landslide in Guide Basin in the Upper Reaches of the Yellow River and its Dammed Lakes. J Remote Sensing \& GIS 4: 147. doi:10.4172/2469-4134.1000147

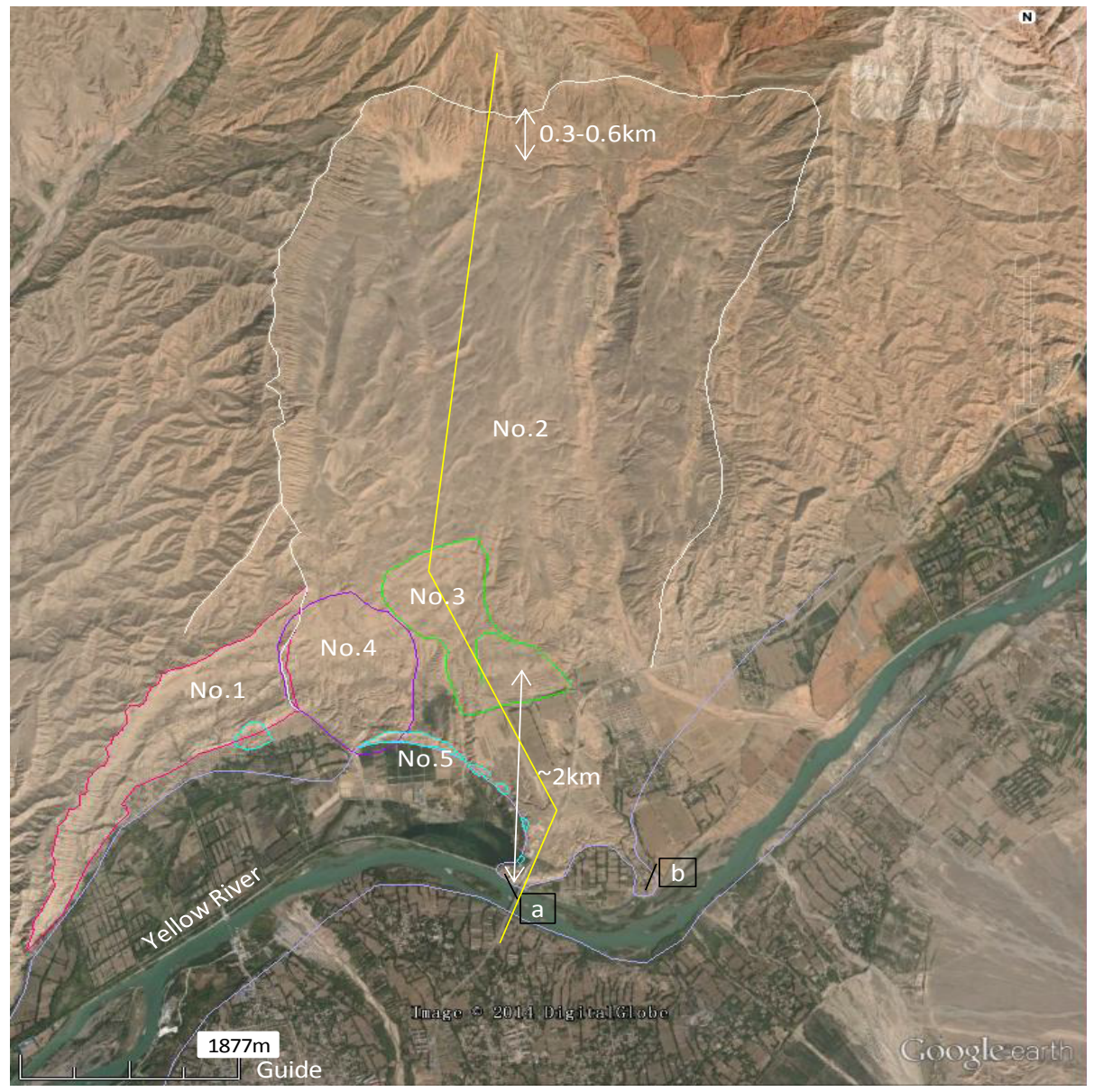

Figure 2: Distribution map of Xijitan landslides. (Red line: landslide of the 1st stage. White line: landslide of the 2nd stage. Green line: landslide of the 3rd stage. Pink line: landslide of the 4th stage. Cyan line: landslide of the 5st stage. Yellow line: section position in Figure 4 . a and b: locations of Figure $5 a$ and 5b. No.1 4: code number of landslides, No.5 is the code of several small-scale landslides).

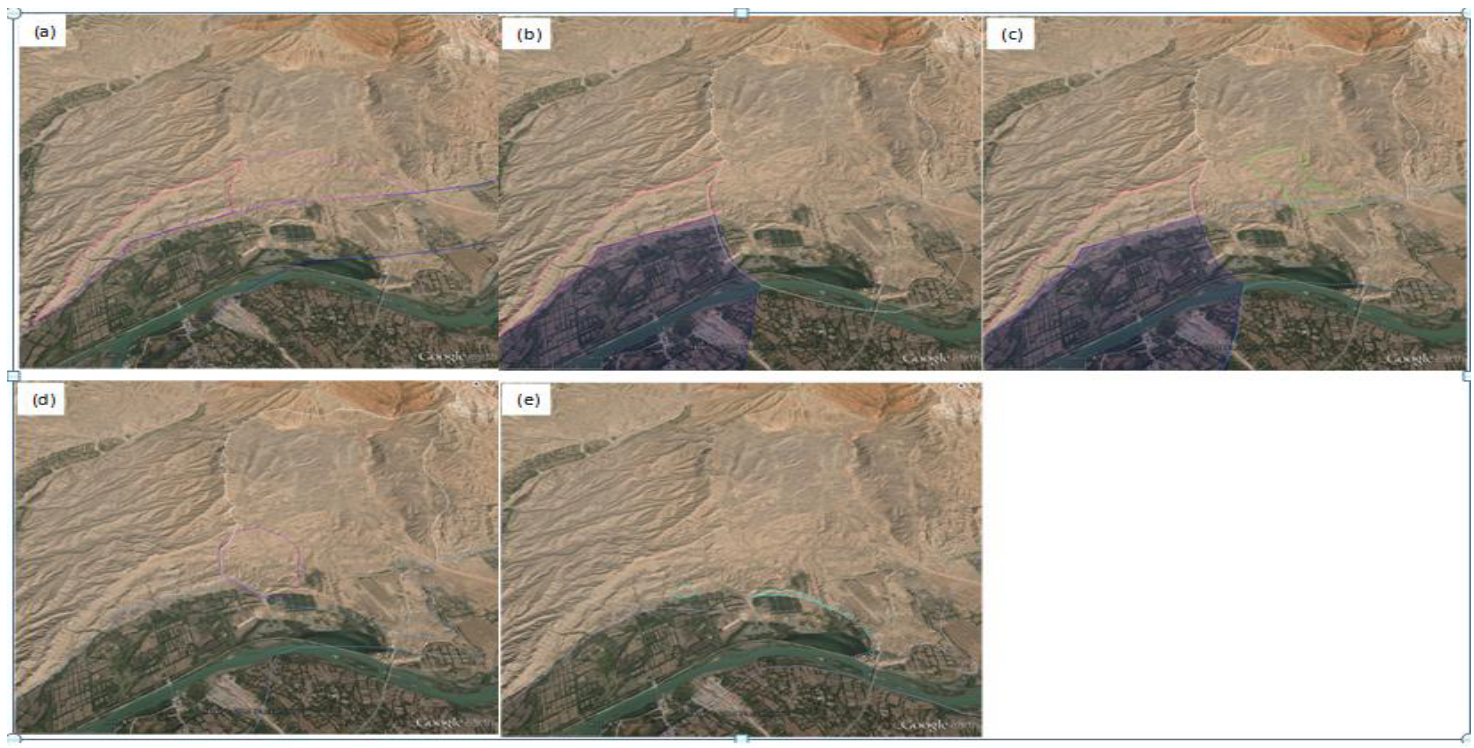

Figure 3: First stages of Xijitan landslides. (a) Stage 1. red: landslide, pink: damaged landlide, blue: river shores; (b) Stage 2. white: landslide, grey white: analyzed landslide front edge, blue region: dammed lake; (c) Stage 3. green: landslide, light blue: river shore, blue region: dammed lake; (d) Stage 4. pink: landslide, light blue: river shore; (e) Sage 5. cyan: landslide, light purple: river shore. 
Citation: Xiaoguang Q, Zhiqiang Y, Wuji Z (2015) Xijitan Landslide in Guide Basin in the Upper Reaches of the Yellow River and its Dammed Lakes. J Remote Sensing \& GIS 4: 147. doi:10.4172/2469-4134.1000147

Page 4 of 6

dating. The ${ }^{14} \mathrm{C}$ age is $6140-6130$ a $\mathrm{BP}$ (cal), suggesting that the Xijitan main landslide occurred in the Holocene Optimum with warm and humid climate.

In the north-south section of the landslide (Figure 5) and the remotely sensed image (Figure 2), the landform of the rear part of the landslide body is an undulating platform with a elevation of $2640 \sim 2540$ $\mathrm{m}$, obviously higher than its front part, showing a steep slope between them. Three drilling cores revealed that the thickness of the landslide body is from $\sim 30$ meters to $\sim 60$ meters (Figure 5), indicating that it is a griddlecake-like landslide.

The top of the front part of the landslide is a platform from 2221 to $\sim 2253$ meters that has been reclaimed as farmland and is about $20 \sim 40$ meters high above the river. Field investigation reveals that there are at least two surfaces of $\sim 2223 \mathrm{~m}$ and $\sim 2245 \mathrm{~m}$ on the platform. It implies that the platform resulted from the erosion of the river of two periods. Thus, it is inferred that the landslide blocked the whole river channel and formed a dammed lake in the upstream. The top platform of the front part of the landslide No. 2 consists of erosion terraces, different from the accumulation property of the second terrace.
Stage 3: When the lake level of the dammed lake rose up the top surface of the front part of the landslide, lake water overflowed the damming body to downstream. Erosion of the river smoothed the top surface of the front part of the main landslide body (No. 2). At the north shore of the river, a new sub-landslide (No. 3, green line) occurred at the steep shore formed by erosion of river (Figure 3c). The front part of the new landslide is a flat platform, indicating the erosion effect of the river (Figure 6). It is inferred that the landslide No. 3 developed at the late period of the stage 3 after the water of the dammed lake overflowed the front platform of the landslide No. 2. After that, the river continuously eroded the front part of the landslide No. 3 .

Stage 4: Because of the erosion of the Yellow River, the front part of the main landslide had been reformed strongly and the main river channel cut through the south of the damming body to lead that the dammed lake disappeared. After that, a sub-landslide (No. 4) occurred at the north shore of the river (Figure 3d). A part of its front part damaged the boundary of the main landslide (No. 2) but another part was eroded by the later river (Figure 6), suggesting that it is late than the landslide No. 3 and early than the later river bend where landslides No. 5 developed along the steep bank. It was inferred that the occurrence

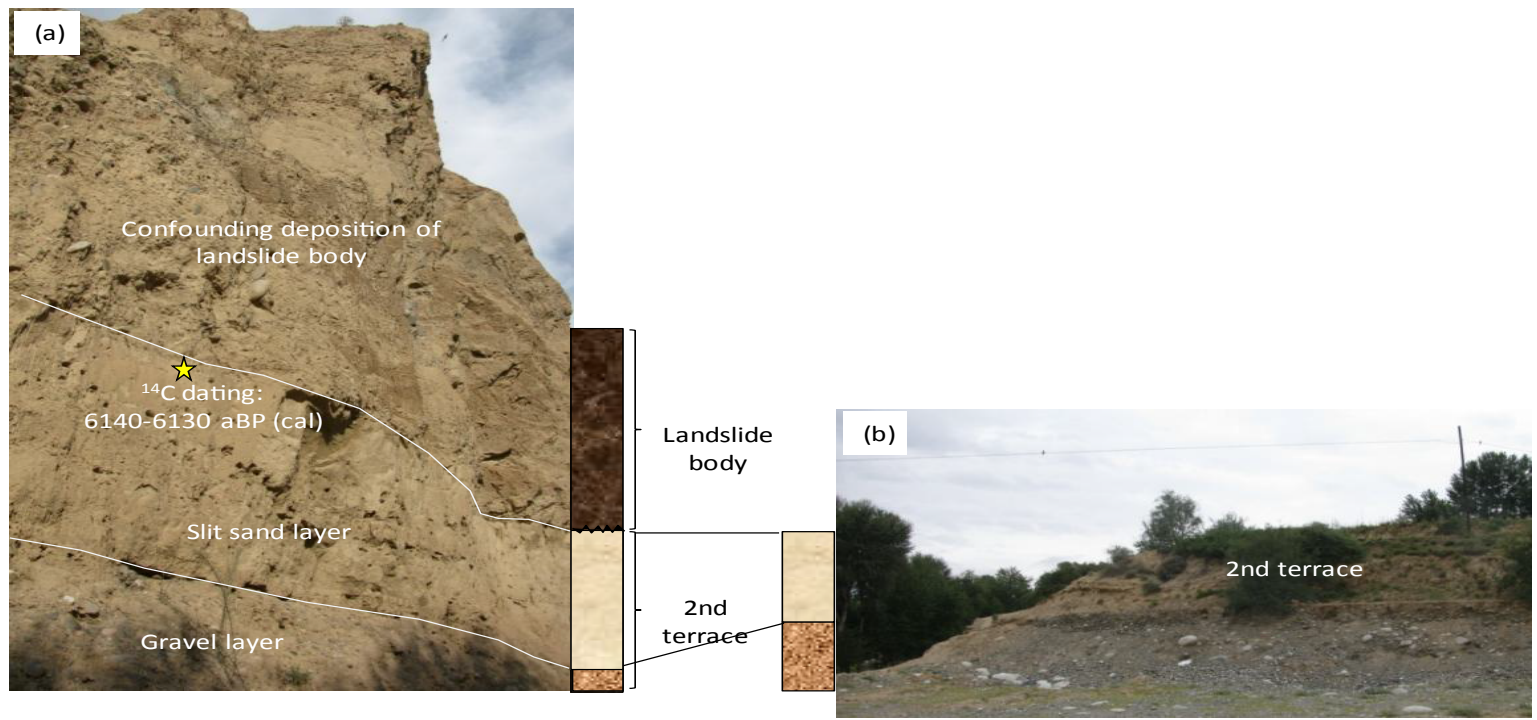

Figure 4: Field photos of the second terrace. (a) Xijitan main landslide overlies the 2nd terrace, (b) the no landslide-overlaid 2nd terrace beside the modern Yellow river channel. (Positions of photos are labeled in Figure 2). Yellow star is the 14C sampled position, the calendar age is $6140-6130$ year BP.

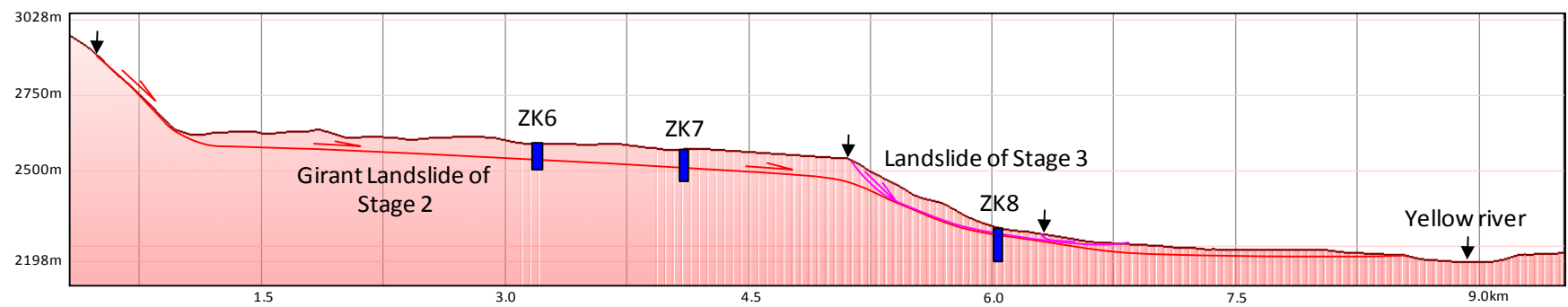

Figure 5: Section of Xijitan landslides (Its position is the yellow line in Figure 2), (Red line: slide surface of stage 2, pink line: slide surface of stage 3, blue column: drilling). 
Citation: Xiaoguang Q, Zhiqiang Y, Wuji Z (2015) Xijitan Landslide in Guide Basin in the Upper Reaches of the Yellow River and its Dammed Lakes. J Remote Sensing \& GIS 4: 147. doi:10.4172/2469-4134.1000147

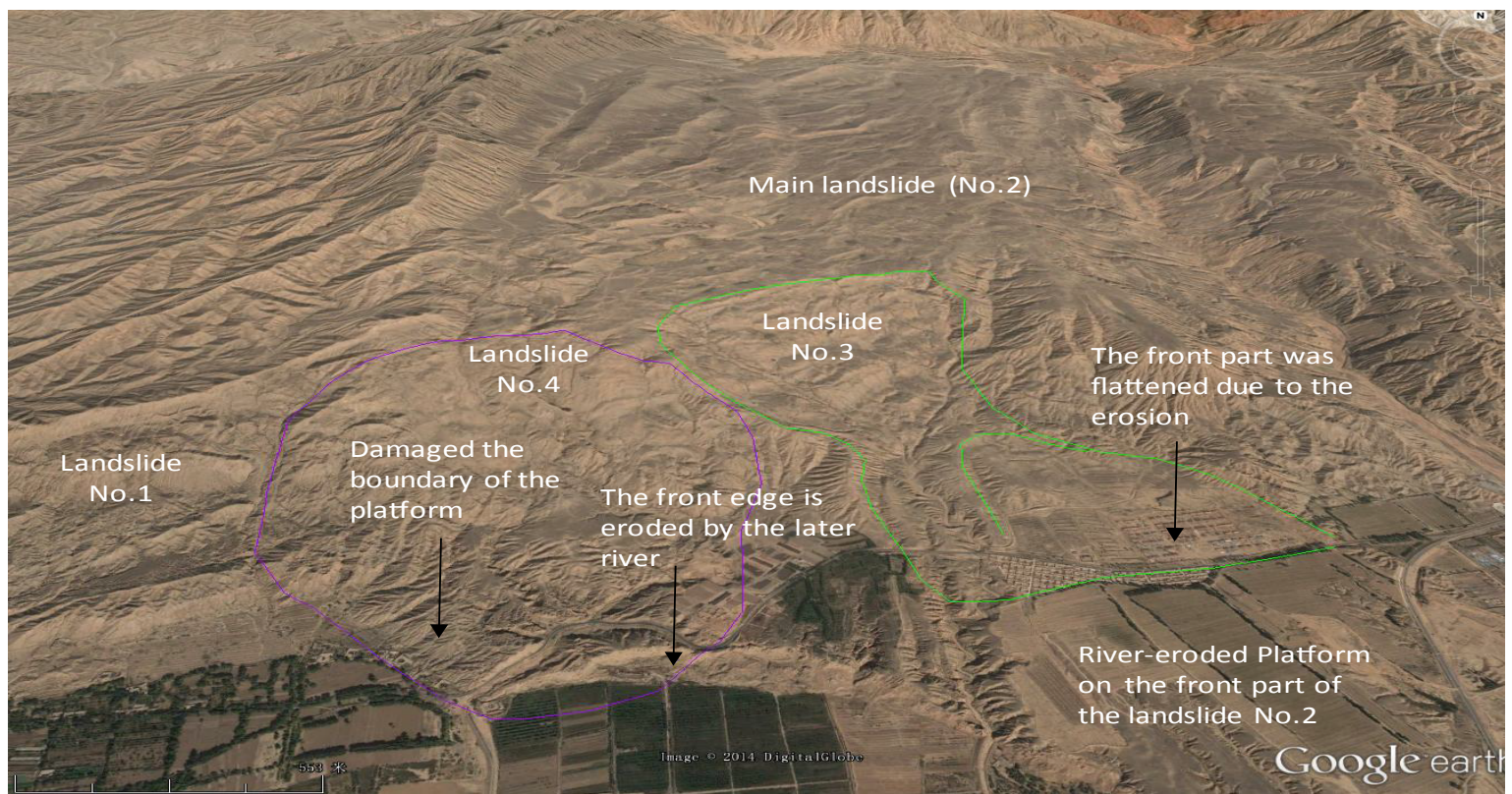

Figure 6: Relation between the landform and sub-landslides. The front part of the landslide No.3 was flattened, suggesting that the river water of dammed lake overflowed and eroded here. In the front part of the landslide No.4, a part reforms the boundary of the front platform of the landslide No.2 and overlies the second terrace, but another part is eroded by the later river, implying that the landslide No.4 is late than the landslide No.3.

of the landslide No. 4 was related to the disappearance of the dammed lake.

Stage 5: The modern Yellow river formed basically. The river eroded the edge of main landslide (No. 2) and other sub-landslides (Figure 3e). Along the erosion-reformed steep slope of the platform, many smallscale landslides (No. 5) developed. These landslides directly impact the activity of modern people.

\section{Triggering mechanism}

The triggering factor of the Xijitan main landslide should be rainfall. The major evidences can be summarized as the following:

(1) Surface deformation: The surface of the rear part of the main landslide (No. 2) is undulating, showing a dough-like plastic deformation characteristic that resulted from water-saturated rocks. It is different from the brittle deformation features of earthquaketriggered dry landslide, such as lack of surface continuity and flexible folds.

(2) Elevation and slope: The Xijitan main landslide (No. 2) is about $8 \mathrm{~km}$ long and $600 \mathrm{~m}$ high from the front edge to the rear edge, suggesting the small slope $\sim 4^{\circ}$. It is unimaginable for an earthquake to trigger the giant landslide in such low slope.

(3) Climate: ${ }^{14} \mathrm{C}$ dating indicates that the Xijitan main landslide (No. 2) occurred after $\sim 6000$ a BP. It is the Holocene Optimum period with warm and humid climate. Thus, rainfall of the period is enough rich to trigger the landslide.

(4) Rock property: The Xijitan landslide consists of semiconsolidated Tertiary mudstone and silk sandstone that are gently inclined strata. The rock property is beneficial for the low-slope movement of water-saturated rock.

\section{Conclusion}

(1) Remote sensing analysis of geological facies and field investigation can help us to reconstruct the landform evolution sequence of landslide and river.

(2) In the study of river terraces, landslides and their dammed lake must be carefully analyzed because they can interfere the analysis of fluvial terrace genesis.

(3) The Xijitan landslide is a landslide group developed in five stages and related to the erosion of the Yellow river and rainfall during the Holocene Optimum.

\section{Acknowledgement}

The study is supported by projects $41372187,41172158,40472094$, and 40024202 of the National Natural Science Foundation of China, the 973 Program (2010CB950200) of the National Basic Research Program of China, the CAS Strategic Priority Research Program (grant no. XDA05120502) and the Knowledge Innovation Program of the Chinese Academy of Sciences (KZCX2-YW-Q1-03).

\section{References}

1. Chen S, Chen GJ, Xu GL (2008) Mechanism of geological processes of formation and deformation of the Huangtupo landslide. Earth Science Journal of China University of Geosciences 33: 411-415 (in Chinese with English abstract).

2. Liu SF, Zhang GW, Pan F, Zhang H, Wang P, et al. (2013) Timing of Xunhua and Guide basin development and growth of the north easternTibetan Plateau,China. Basin research, 25: 74-96.

3. Chen GJ, Li CA, Chen S, Shao L (2013) Landslide development and the geological process of watercourse evolution in the Three Gorges Reservoir Area. Earth Science Journal of China University of Geosciences 38: 411-415 (in Chinese with English abstract).

4. Yin ZQ, Cheng GM, Hu G,Wei G, Wang Y, et al. (2010) Preliminary study on characteristic and mechanism of super large landslides in the upper Yellow River since late Pleistocene. Journal of Engineering Geology 18: 41-52(in Chinese with English abstract). 
Citation: Xiaoguang Q, Zhiqiang Y, Wuji Z (2015) Xijitan Landslide in Guide Basin in the Upper Reaches of the Yellow River and its Dammed Lakes. J Remote Sensing \& GIS 4: 147. doi:10.4172/2469-4134.1000147

5. Yin ZQ, Zhao WJ (2013a) Some Giant Landslides from Sigouxia Gorge to Laganxia Gorge in NE Tibet Plateau since the Late Glacial. Acta Geologica Sinica 87: 413-417.

6. Yin ZQ, Qin XG, Zhao WJ (2013b) Study on the landslide developmental characteristics in the upper reaches of the Yellow River NE Tibet Plateau[J]. Acta Geologica Sinica 87(z1): 418-419.

7. Yin ZQ, Qin XG, Yin YP, Zhao W, Wei G (2014) Landslide Developmental Characteristics and Response to Climate Change since the Last Glacial in the upper reaches of the Yellow River, NE Tibetan Plateau. Acta Geologica Sinica 88: 635-646.

8. Pan BT, (1994) A study on the geomorphic evolution and development of the upper reaches of Yellow River in Guide basin. Arid land geography 17: 43-48 (in Chinese with English abstract).

9. Bi HL, Zhao JX, Sui J (2009) Survey report on geological disaster in detailed of Guide County. The Station of geological environment monitoring of Qingha Province, 108-120 (in Chinese). 